\title{
Application of derivatives of incomplete wheat-wildrye amphiploid (WWRA) Elytricum fertile in selection of winter soft wheat
}

\author{
I. Motsnyi, \\ candidate of biological science \\ T. Narhan, \\ candidate of agricultural sciences \\ M. Yeryniak, \\ candidate of agricultural sciences \\ S. Lyfenko, \\ academician, doctor of agricultural sciences \\ Plant Breeding and Genetics Institute - National Center of Seed and Cultivar Investigations
}

The purpose. To sum up results of long-term probes and to determine according to agronomic attributes difference and selection worth of perspective lines of wheat, derivants wheat-wild-rye amphiploid (WWRA). Methods. Field - for determination of productivity, autoadaptivity and resistance of material; laboratory for determination of merit numbers of flour and genetic formulas of locuses of reserve proteins of the subject of inquiry; statistical - for determination of reliability of the gained results. Results. The selection assessment of 2 perspective lines, derivatives of amphiploid Elytricum fertile in comparison with modern grades is made. Conclusions. Use in remote hybridization of WWRA Elytricum fertile can be successful for selection of winter soft wheat. The high-yielding variety created thus is entered in the State registry and used in primary and elite seeds growing and powered up in the further selection process.

Key words: soft wheat, wheat-wild-rye amphiploid, derivative lines, productivity, quality.

Breeding of winter wheat is developed on the basis of a "flash" and "growing up." After another "flash" the increase in the guaranteed yield is $2.5-3.0 \mathrm{c} / \mathrm{h}$ a with every new cultivar, and ultimately reaches $8.0-10.0 \mathrm{c} / \mathrm{ha}$. Such gradual improvement of the genotypes may provide significant results, but eventually weakened. The exhaustion of an outstanding genotype used as the starting material is explained to cause the attenuation. Only a creation of fundamentally new genotypes that would become a landmark in breeding can be the way out of this situation [5]. An involvement of any genetic information from other species by wide hybridization is considered to be a promising way of obtaining of such genotypes. This area is basically not new, if we take into account, for example, crosses of wheat with wheat grass species. Start of such research is approaching the 100th anniversary in the former Soviet Union and Canada [2,12]. Many other studies from interspecific hybridization were conducted and very interesting results in terms of wheat genetics were obtained, but there was not so much success in practical breeding [9]. Getting the right gene combination seems to be much harder in interspecific hybridization, than in the intra specific crosses. Nevertheless, the probability of an outstanding genotype creation, which could become a landmark, is still much higher.

Search for other species that share positive genes towards wheat cytoplasm may become a promising area of breeding. In this respect, it is also about the possibility of anchored intergenomic and nuclearcytoplasmic heterosis. In addition, elements of alien nuclear structures are not only a source of recombinant changes in interspecific crosses, but also they can cause different types of wheat genome micromutations that may also be useful for breeding. However, one should be borne in mind, that bread wheat breeding involving wild or other cultural species can achieve a significant positive result, but also the positive genes can be transferred into cultural wheat together with unwanted properties of its relatives, such as susceptibility to diseases.

Among the wild, although distant, wheat relatives the genera Elymus L. from the tribe Triticeae Dum. is of some interest for botanists and breeders. This is perennial species, resistant to many diseases and abiotic 
factors. With the modern techniques of biotechnology, hybrids between Elymus species and wheat have been received in the best scientific institutions of the world, particularly the amphiploid Elytricum fertile, which we have used for future crosses.

The aim of the research - to identify for agronomically valuable characteristics a difference and a breeding value of two perspective constant lines: derivatives from the amphiploid Elytricum fertile, which were selected from the huge material obtained as a result of crossing of backcrossed hybrids with the best at that time wheat cultivars of PBGI - NCSCI.

Materials and methods of research. Two perspective breeding lines: Erytrospermum 4513-06 (hereafter 4513-06) and Erytrospermum 4517-06 (4517-06), obtained by complicated stepped crosses, were used as the material for the study. Line 4513-06 derived from crosses SES96-99/Zirka//Nykoniya, and the line 4517-06 - Odesskaya 267/ChE1342-98//Odesskaya 267*3. In turn, SES96-99 is a primitive introgression line (2n=42) $B C_{1} F_{\infty}$ Salmon (Japan)/Elytricum fertile//Salmon, and ChE1342-98 - genome-substituted form $\left(2 n=42 ;\right.$ AABBS' $\left.^{t}\right) \mathrm{F}_{\infty} T$. durum cv. Chernomor/Elytricum fertile [10]. PWEA Elytricum fertile (T. aestivum/E. sibiricus; $2 n=8 x=56$, AABBDDS's ${ }^{t}$ ), which was kindly provided by R. Franke (Germany), contains 42 chromosomes of bread wheat and 14 chromosomes of one of E. sibiricus genomes.

Experiment was laid on black steam by single block with three replications. Seeds were sown in optimal terms by the tractor drill SSFK-7 in plots of $10 \mathrm{~m}^{2}$ and $25 \mathrm{~m}^{2}$ at the rate of 450 germinated grains per $1 \mathrm{~m}^{2}$. The plots were placed in the control nursery (2006 and 2007), previous (2008) and competitive (2009-2011) strain testing at the rotation of $\mathrm{PBGI}-\mathrm{NCSCl}$ laboratory of breeding of intensive wheat cultivars to determine the line performance and quality. The modern high-grade PBGI - NCSCl cultivars: Albatross odesskyi (hereafter Albatross), Selyanka, Victoria odesskaya (Victoria) and Kuyalnyk were taken as standards. Farming equipment was common for seed sowing of South Ukraine area: predecessor - black steam. The line constant, frost resistance, productivity and display of agronomic traits at agrocenosis were determined during the growing season, harvesting and threshing plant.

Plant pathological evaluation was carried out during 2007-2011 (Table 1) in the field on a background of natural epiphytoties of powdery mildew, leaf rust, Septoria and Pirenophora and artificial infectious pressure of leaf and stem rust with 9-point integrated scale [1]. Freezing of germs was carried in the paper rolls [3]. Frost resistance was also evaluated by V.Ya. Yuriev methods - direct freezing of plants at the tillering stage in planted boxes at $\mathrm{t}=-19^{\circ} \mathrm{C}[6]$.

Electrophoresis of storage proteins was performed at the Department of the genetic basis of breedin for the original [7] and modified method of SDS electrophoresis [11]. Herewith, genetic formulas of loci and names of gliadin and glutenin alleles were determined, respectively, for the catalogs of F.O. Poperelya [7] and P.I. Payne [11]. Determination of protein content and quality of flour were conducted respectively using infrared spectroscopy and sedimentation value method SDS30 [8].

Results and discussion. Two perspective breeding lines (4513-06 and 4517-06) have been received as a result of the complicated stepped crosses at the base of cultivars Nikoniya and Odesskaya 267. The lines have high yield $(59,2-79,7$ and 59,6-77,8 c/ha, standards $-41,1-78,6 \mathrm{c} / \mathrm{ha}$ ), quality (sedimentation value $84-$ 91 and $83-90 \mathrm{ml}$, standards $-69-91 \mathrm{ml}$ ), winter hardiness ( $5+$ and 5 balls) and resistance to rust species (6-8 balls) originating from amphiploid Elytricum fertile (Table 1, 2). 
1. Characteristics of perspective lines derived from PWEA Elytricum fertile, for certain characters (2007-2011)

\begin{tabular}{|c|c|c|c|c|c|c|c|c|c|}
\hline & \multirow{2}{*}{ Material } & \multicolumn{4}{|c|}{ Resistance to* (ball) } & \multirow[t]{2}{*}{ FR., ${ }^{* *} \%$} & \multirow{2}{*}{$\begin{array}{l}\text { WH., } \\
\text { ball }\end{array}$} & \multirow{2}{*}{$\begin{array}{l}\mathrm{PH}, \\
\mathrm{cm}\end{array}$} & \multirow{2}{*}{$\begin{array}{l}\text { DE, } \\
\text { May }\end{array}$} \\
\hline & & Pm & Lr & $\mathrm{Sr}$ & Stb & & & & \\
\hline \multirow{5}{*}{ 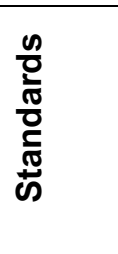 } & Albatross & $3-6$ & $2-6$ & 4 & $3-4$ & $57,0 \pm 14,2$ & $4 \ldots 5$ & $72-104$ & $12-19$ \\
\hline & Victoria & $5-6$ & $5-6$ & - & - & - & $4 \ldots 5+$ & 86-107 & $13-20$ \\
\hline & Selyanka & $3-5$ & $1-4$ & $2-4$ & $3-4$ & $55,8 \pm 11,7$ & $4-\ldots 5$ & $74-104$ & $12-19$ \\
\hline & Kuyalnyk & $5-6$ & $5-6$ & $3-4$ & 5 & $63,4 \pm 12,5$ & $4+\ldots 5$ & $95-113$ & $12-19$ \\
\hline & Odesskaya 267 & $4-5$ & $2-4$ & $2-5$ & $3-4$ & $41,0 \pm 13,8$ & $4+\ldots 5+$ & $82-110$ & $14-21$ \\
\hline \multirow{5}{*}{ 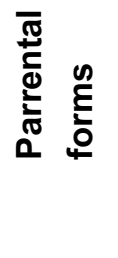 } & SES96-99 & 5 & $5-8$ & 2 & $7 ; 4$ & $54,4 \pm 13,3$ & $3 \ldots 5-$ & $125-158$ & $18-25$ \\
\hline & ChE1342-98 & 8 & 7-8 & 5 & $5-7$ & $43,1 \pm 15,4$ & $4-\ldots 5-$ & $95-98$ & $21-23$ \\
\hline & Perspective lines & & & & & & & & \\
\hline & 4513-06 & $4-7$ & $6-8$ & $6-7$ & $4-7$ & $62,5 \pm 10,0$ & $4-\ldots 5+$ & $70-95$ & $12-19$ \\
\hline & $4517-06$ & $4-7$ & $5-7$ & $7 ; 5$ & $5-6$ & $69,6 \pm 8,2$ & $3+\ldots 5-$ & 63-105 & $12-19$ \\
\hline t. & $\mathbf{m}, \mathrm{Lr}, \mathrm{S}$ & . & & vari & & & & of ex & ence \\
\hline
\end{tabular}

2. Yield capacity and quality of perspective lines derived from PWEA Elytricum fertile, against the cultivars-standards (2006-2009)

\begin{tabular}{|c|c|c|c|c|c|c|c|c|c|c|c|}
\hline \multirow{2}{*}{ Material } & \multicolumn{4}{|c|}{ Yield*, c/ha $^{*}$} & \multicolumn{2}{|c|}{ WTK $^{*}, \mathbf{g}$} & \multicolumn{2}{|c|}{ Pr. ${ }^{*}, \%$} & \multicolumn{3}{|c|}{ Sed. ${ }^{*}, \mathrm{ml}$} \\
\hline & 2006 & 2007 & 2008 & 2009 & 2008 & 2009 & 2008 & 2009 & 2007 & 2008 & 2009 \\
\hline Albatross & 45,3 & 68,2 & 72,5 & 62,6 & 35,3 & 34,8 & 14,3 & 13,1 & 73 & 91 & 89 \\
\hline Victoria & 41,1 & 60,0 & 63,1 & 75,3 & 33,4 & 35,1 & 13,6 & 11,6 & 69 & 70 & 73 \\
\hline Selyanka & 52,0 & 69,1 & 72,2 & 65,8 & 35,2 & 35,5 & 14,0 & 12,4 & 75 & 86 & 84 \\
\hline Kuyalnyk & 47,3 & 71,5 & 74,7 & 78,6 & 39,4 & 36,8 & 14,3 & 10,3 & 82 & 90 & 87 \\
\hline Odesskaya 267 & 49,5 & 65,3 & 52,4 & 73,4 & 39,2 & 37,4 & 13,5 & 13,6 & 70 & 93 & 88 \\
\hline $4513-06$ & 59,2 & 67,8 & 72,0 & 79,7 & 47,2 & 33,5 & 12,9 & 9,6 & 91 & 84 & 84 \\
\hline $4517-06$ & 59,6 & 67,7 & 72,1 & 77,8 & 39,5 & 39,5 & 12,8 & 9,7 & 83 & 90 & 90 \\
\hline \multicolumn{12}{|c|}{$\begin{array}{l}\text { Note:* Yield - yield capacity; WTK - weight of } 1000 \text { kernels; Pr. - protein content; Sed. - } \\
\text { sedimentation SDS30. }\end{array}$} \\
\hline
\end{tabular}

Line 4513-06 from introgression cross (SES96-99/Zirka//Nykoniya) was assigned as a common cultivar of laboratory of breeding of intensive wheat cultivars and the department of general and molecular genetics of $\mathrm{PBGI}-\mathrm{NCSCl}$ at the state varietal trial called Vigen (application number 11007011) in 2011. The cultivar Vigen has significant advantages over the best cultivars-standards for a complex of economically useful traits: yield, frost resistance-winter hardiness, disease resistance etc. (Table 3). Since 2014, it has been listed in the State register of plant varieties suitable for dissemination in Ukraine [4].

3. Economic useful characters of cultivar Vigen (cultivars testing on a black steam, the average longterm indicators of PBGI - NCSCI, 2010-2016).

\begin{tabular}{|c|c|c|c|c|c|}
\hline \multirow[b]{2}{*}{ Cultivar } & \multirow[b]{2}{*}{$\begin{array}{l}\text { Yield, } \\
\text { c/ha }\end{array}$} & \multirow{2}{*}{$\begin{array}{l}\text { Frost resistance }{ }^{*}, \\
\% \text { alive plants after freezing at } \\
\mathrm{t}=-19^{\circ} \mathrm{C}\end{array}$} & \multicolumn{3}{|c|}{ Resistance to diseases ${ }^{*}$, ball } \\
\hline & & & $\begin{array}{l}\text { powdery } \\
\text { mildew }\end{array}$ & leaf rust & $\begin{array}{l}\text { Pireno- } \\
\text { phora }\end{array}$ \\
\hline Vigen & 81,5 & 84,4 & 4 & 4 & 4 \\
\hline $\begin{array}{l}\text { Victoria } \\
\text { (standard) }\end{array}$ & 73,2 & 39,1 & 4 & 1 & 3 \\
\hline LSD $_{0,05}$ & 3,8 & 10,6 & & & \\
\hline
\end{tabular}


Increasing demands for the baking quality of the grain of new wheat cultivars require further study of the character genetic determinants, including genetic control of storage protein components. Therefore, the analysis of electrophoretic separations was performed (figure) and the genetic formulas of the material for ten main gliadin and glutenin loci were identified (Table 4). Herewith the cultivar Vigen was established to consist of different biotypes for the certain alleles. In general, a set of Gld (gliadin) loci alleles is characteristic for typical cultivars of southern Ukraine. Only allele Gld1B2 (distinctive for one of the cultivar Vigen biotypes) occurs rare, as associated with low quality and Gld6B4 allele is rare and little known. Thus, allele Gld1A6 and new for wheat allele GId1DN from amphiploid Elytricum fertile or allele Gld1B3m (marks 1BL.1RS translocation) from line Salmon were not transferred to the cultivar. Obviously, this is due to the selection for high flour baking quality.

The high-molecular glutenin alleles Glu-A1(1), Glu-B1(7+8), Glu-B1(7+9), Glu-D1(5+10), typical for most cultivars of Ukrainian breeding, were identified in cultivar Vigen. Herewith quality index of allele Glu-B1(7+8) is higher, than allele Glu-B1(7+9). Unfortunately, the alleles Glu-A1(2*) from the PWEA and Glu-B1(77+8) from Salmon, associated with extra high quality flour, have not been transferred. Nevertheless, the poor quality allele Glu-D1(2+12) inherent in parental forms, has also not been inherited (Table 4).

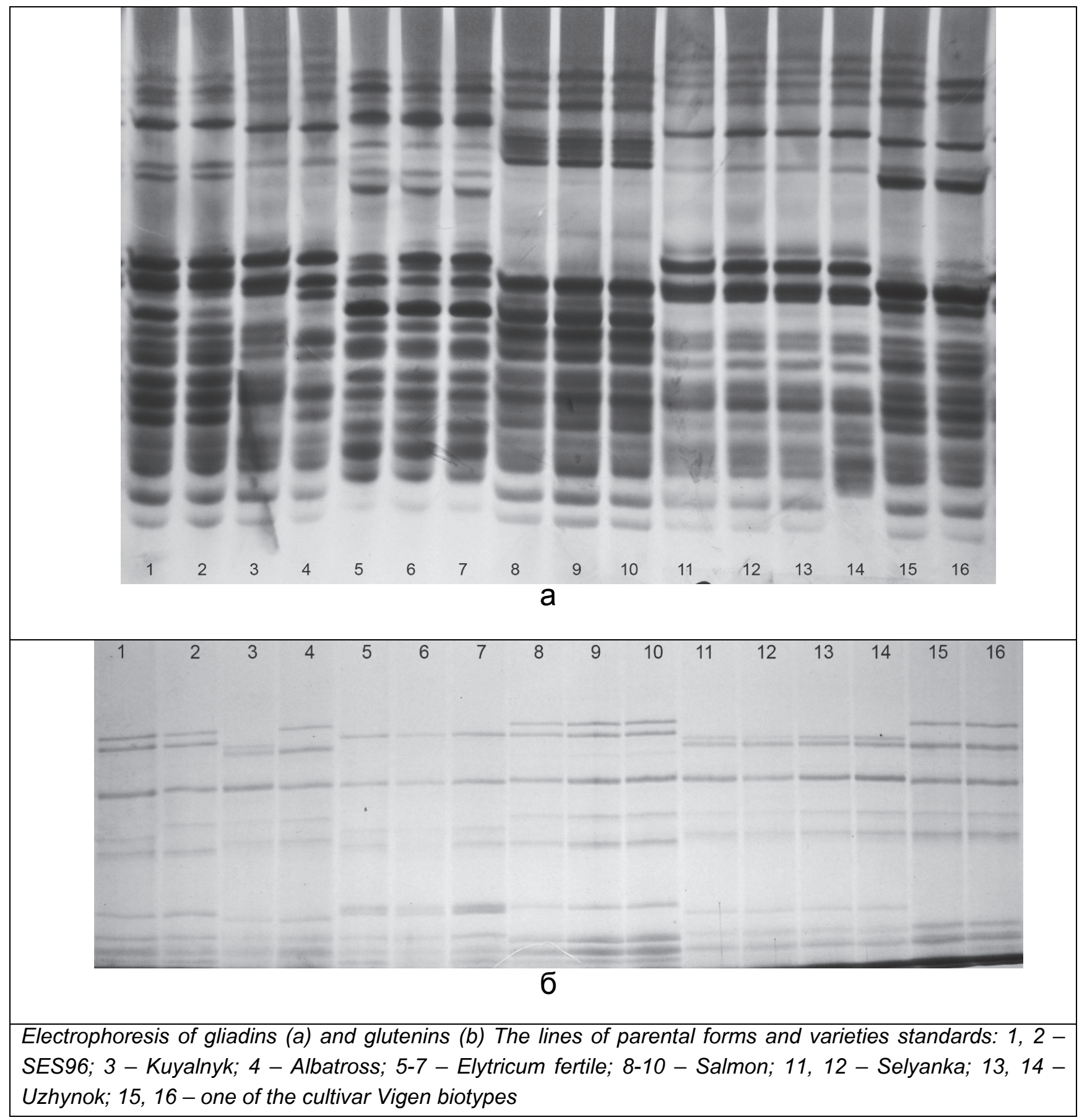


Thus, cultivar Vigen has alleles of fibrinous protein both typical for most cultivars of steppe Ukraine with satisfactory quality, and of rare (only gliadins) and has no alleles (Gld1A10, Gld1B15, GId1D5, Glu-A1(2*), Glu-B1(77+8)), characteristic for extra strong wheat genotypes (Panna, Selyanka, Kuyalnyk, Zmina etc.). Despite that, cultivar Vigen surpasses the best known varieties (Kuyalnyk, Victoria) for the technological qualities of grain, "power" of flour reaches 420 p.a.; while in some years, with excess rainfall during harvest the cultivar reduces the quality indexes of less extent, than representatives of extra strong wheat.

\section{Genetic formulas of allelic state of fibrinous protein loci at cultivar Vigen, parental forms and the cultivars-standards}

\begin{tabular}{|c|c|c|c|c|c|c|c|c|c|c|}
\hline \multirow{2}{*}{ Material } & \multicolumn{7}{|c|}{ Gliadins } & \multicolumn{3}{|c|}{ High-molecular glutenins } \\
\hline & $1 \mathrm{~A}$ & 1B & 1D & $6 A$ & $6 B$ & 6D & $2-1 A$ & $1 \mathrm{~A}$ & 1B & 1D \\
\hline SES96 & 5 & $\mathrm{~N}^{\#}$ & $\mathrm{~N}$ & 4 & 1 & 2 & 3 & 1 & $77+8+7+9$ & $2+12$ \\
\hline Kuyalnyk & 10 & 1 & 4 & 4 & 2 & 2 & 3 & $2^{*}$ & $77+8$ & $5+10$ \\
\hline Albatross & 4 & 1 & 4 & 4 & 2 & 3 & 3 & 1 & $7+8$ & $5+10$ \\
\hline $\begin{array}{l}\text { Elytricum } \\
\text { fertile }\end{array}$ & 6 & $\mathrm{~N}$ & $\mathrm{~N}$ & 4 & 1 & 2 & 1 & 0 & $7+9$ & $2+12$ \\
\hline Salmon & 6 & $3 m^{*}$ & $\mathrm{~N} / 1^{\#}$ & 4 & 2 & 2 & $1 ?$ & 1 & $7+8+77+8$ & $2+12$ \\
\hline Selyanka & 10 & 1 & 4 & 4 & 2 & 2 & 3 & $2^{*}$ & $77+8$ & $5+10$ \\
\hline Vigen & $4+5$ & $2+1$ & $4+1^{\#}$ & 3 & 4 & 2 & 3 & 1 & $7+8+7+9$ & $5+10$ \\
\hline
\end{tabular}

Numerous tests of cultivar Vigen after adding it to the "State register" confirm its constant high yield (Table 3), and in terms of the breadmaking quality it remains in a group of strong cultivars. For example, in the fullest strain testing in 2016 the cultivar had a yield of $70.6 \mathrm{c} / \mathrm{ha}$. Cultivars-standards Kuyalnyk and Victoria - 66.9 and 66.3 c/ha, respectively. "Power" of flour of cultivar Vigen was 420 p.a. (cultivarsstandards -530 and 340 p.a., respectively).

Line 4517-06 from the cross Odesskaya 267/ChE1342-98//Odesskaya $267^{* 3}$ did not show for years of research any significant benefits under standards for the complex of agronomic traits. Depending on the year weather conditions, the line was $10-20 \mathrm{~cm}$ shorter the parental form - Odesskaya 267 and was involved in subsequent crosses with the recurrent cultivar Odesskaya 267 to create a short stemmed isogenic line.

\section{Conclusions}

Involvement in wide hybridization of wheat-Elymus amphiploid Elytricum fertile can be effective for winter bread wheat breeding. From the introgression cross with its participation, two highly yielded perspective lines adapted to desert conditions of South Ukraine have been received. One of them called Vigen successfully passed state strain testing. For a set of economically useful traits: yield capacity, photoperiod insensitivity, frost resistance-winter hardiness, disease resistance, technological baking quality of the grain etc. cultivar Vihen has significant advantages over the best cultivars-standards. In 2014, it was entered into the State register of plant varieties suitable for dissemination in Ukraine (application number 11007011). The second line was involved in saturating crosses with the recurrent cultivar Odesskaya 267 to create a short stemmed isogenic line for genetic research.

\section{Bibliography}

1. Babayants O.V., Babayants L.T. Bases of breeding and methodology of evaluations of wheat to pathogens of diseases. - Odesa: BMB, 2014. - $401 \mathrm{p}$.

2. Verushkin S.M. Hybridization of wheat with wheatgrass. - Saratov: Gosizdat, 1935. - 38 p.

3. Gavrilov S.V. Frost resistance of shoots of winter wheat genotypes in paper rolls with different doses of mineral nutrition // Coll. sci. papers of PBGI - NCSCI. - Odesa, 2002. - Is. 2 (42). - P. 76-81.

4. State register of plant varieties suitable for dissemination in Ukraine in 2016. - Kyiv, 2016. [Electronic resource]. - Access: http://www.vet.gov.ua/sites/default/files/Reestr 22.02.16.pdf 
5. Litvinenko M.A. Department of wheat breeding and seed investigation in 100-year history of the institute // Coll. sci. papers of PBGI $-\mathrm{NCSCl}$ by the $100^{\text {th }}$ anniversary of the Institute is dedicated. - Odesa, 2012. - P. 11-27.

6. Lyfenko S.F., Narhan T.P., Nakonechnyi M.Yu. Introgressions into bread wheat genome from various donors - the troubled but promising direction of breeding // Interdepartmental thematic sci. collection "Breeding and seed investigation" of V.Ya. Yuriev Institute of plant growing. - Kharkiv. - 2014. - Is. $105-$ P. 39-50.

7. Poperelya F.O. Three main genetic system of grain quality of winter bread wheat // Coll. sci. papers "Realization of potential possibilities of varieties and hybrids of Plant Breeding and Genetics Institute in terms of Ukraine". - Odessa, 1996. - P. 117-132.

8. Rybalka O.I., Chervonis M.V., Toporash I.G., Surzhenko I.A., Bodelan O.P., Shcherbyna Z.V. Scientific substantiation of development of new methods for evaluation of the baking quality of wheat flour // Refining and storage of grain. - 2006. - № 1 (79). - P. 43-48.

9. Sinyak E.V., Volkova G.V., Mitrofanova O.P. Sources of resistance of wheat and Aegilops to stem rust (causative agent of Puccinia graminis Pers. f. sp. tritici Erikss et. Henn) // Scientific Journal of KubSAU, 2011. - №. 67 (03). [Electronic resource]. - Access: http://ej.kubagro.ru/2011/03/pdf/23.pdf.

10. Motsnyy I.I., Procopovich E.L. Development of bread wheat-Elymus sibiricus substitution stocks as a result of crosses between tetraploid wheats and octoploid PWEA Elytricum fertile//Genetic collections, isogenic and alloplasmic lines: Th. rep. Int. Conf. 30 July-3 August, 2001. - Novosibirsk (Russia), 2001. - P. 198-200.

11. Payne P.I., Holt L.M., Jackson E.A., Law C.N. Wheat storage proteins: their genetics and their potential for manipulation by plant breeding//Phil. Trans. R. Soc. Lond. - 1984. - B. 304. - P. 359-371.

12. Peto P.H. Hybridization of Triticum and Agropyron. II. Cytology of the male parents and $F_{1}$ generation//Canad. J. Res. C. - 1936. - Vol. 14, № 5. - P. 203-214. 